\title{
Relayout Production Facility of PC. Spun Pile Using Systematic Layout Planning in ABC Factory
}

\author{
Muhammad Ainun Naim ${ }^{1}$, Erry Rimawan ${ }^{2}$, Mahmud $^{3}$, Adinda Putri ${ }^{4}$ \\ Department of Industrial Engineering ${ }^{1,2}$, Department of Magister Management ${ }^{3,4}$ \\ Mercu Buana University, Jakarta, Indonesia
}

\begin{abstract}
ABC Factory is one of the companies engaged in manufacturing precast concrete in Indonesia. This company was established in 1978 under the auspices of XYZ Group Since. The products produced by ABC Factory are Precast Concrete / Prefabricated Concrete or often abbreviated as "PC". Some of the products manufactured by ABC Factory are PC. Spun Pile, PC. Square Pile, PC. Spun Pole (Electric Pole), PC. I Girder, PC. Box Girder and several other products. ABC Factory uses the Make to Order production method, so it is demanded to produce orders maximally and as efficiently as possible.
\end{abstract}

In this manufacturing company, the preparation of the layout of production facilities greatly affects the production cycle time which in turn will have a major effect on the company's production capacity. for that, the company needs to redesign the layout of the PC production facility of Spun Pile with the best production flow. Based on these problems, the method used is to use the SLP (Systematic Layout Planning) method which functions to produce a layout design for production facilities that minimizes material movement distance and produces a good production flow in ABC Factory.

Based on the results of the study obtained a reduction in the distance of material flow facility layout by 72.71 meters and an increase in production capacity of 138 cigarettes or $13.44 \%$ of the initial layout.
Keywords:- Facility Layout Design, Cycle Time, Systematic Layout Planning (SLP).

\section{INTRODUCTION}

$\mathrm{ABC}$ Factory is one of the companies engaged in manufacturing precast concrete in Indonesia. This company was established in 1978 under the auspices of PT. Pembangunan Jaya Group. Since 41 years ago ABC Factory took part in meeting the needs of precast concrete in Indonesia.

Along with the rapid development in several regions of Indonesia both projects funded by the government and by foreign parties, making entrepreneurs not hesitate to invest in manufacturing precast concrete. This was shown by the increasing number of precast concrete companies, so that competition in the industry of selling precast concrete products became tighter. Thus ABC Factory must conduct an evaluation of the productivity generated in order to face the increasingly fierce competition.

PC Spun Pile or often called concrete piles is one of the superior products owned by $\mathrm{ABC}$ Factory and the product is also a product that is much needed in every project.

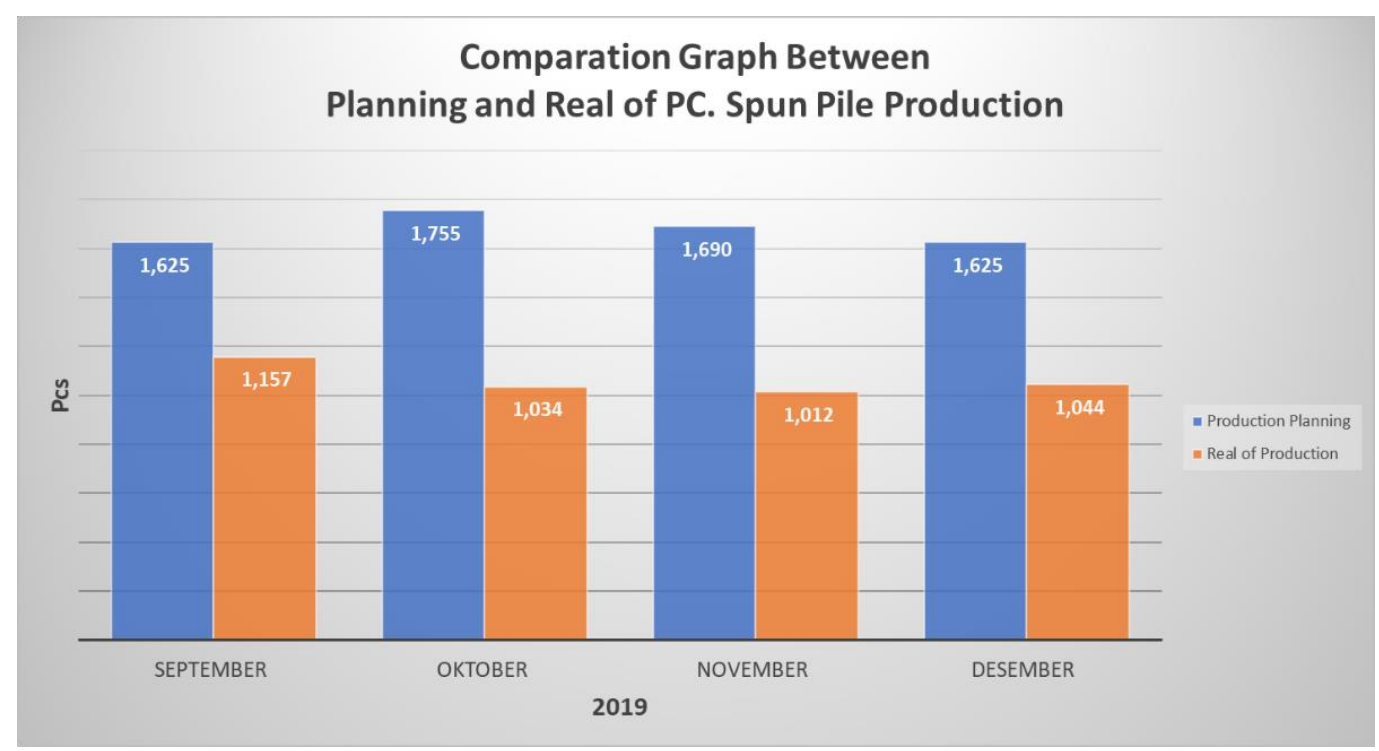

Fig 1:- Comparison Table of Sadang Factory Production Results September - December 2019 
From the above data it can be seen that the production of the Sadang PC Spun Pile factory from September December 2019 did not meet the targets given by the company. so it needs to be done an analysis of improvements to achieve the targets given by the company in the next period. Where the target given by the company always goes up from year to year

Production layout analysis is carried out based on the results of the shortest material transfer distance and the most efficient production flow. The purpose of this research is not only to study various activities, supporting facilities and production layout available in the production section of the PC Spun Pile product and to be able to recommend a new layout design for the production area related to the optimization obtained in terms of the distance of material flow and costs material handling using the SLP (Systematic Layout Planning) method.

\section{REVIEW OF LITERATUR STUDY}

\section{Layout Facility}

Layout according to Apple (1990), layout is a process of designing and managing physical facilities such as machinery and equipment, land, buildings and spaces to optimize the linkages between workers, material flow, information flow and methods needed in order to efficiently achieve company goals, economical and safe.

According to Wignjosoebroto (2009), factory layout or facility layout can be defined as the procedure for managing factory facilities to support the smooth production process. This arrangement will be useful for the area of placement of machinery or other supporting production facilities, the smooth movement of material movements, temporary and permanent material storage, workers' personnel and so on

To analyze the next process. Like the production flow system and material handling methods. There are four types or types of layouts that are classically commonly applied in layout design, namely:

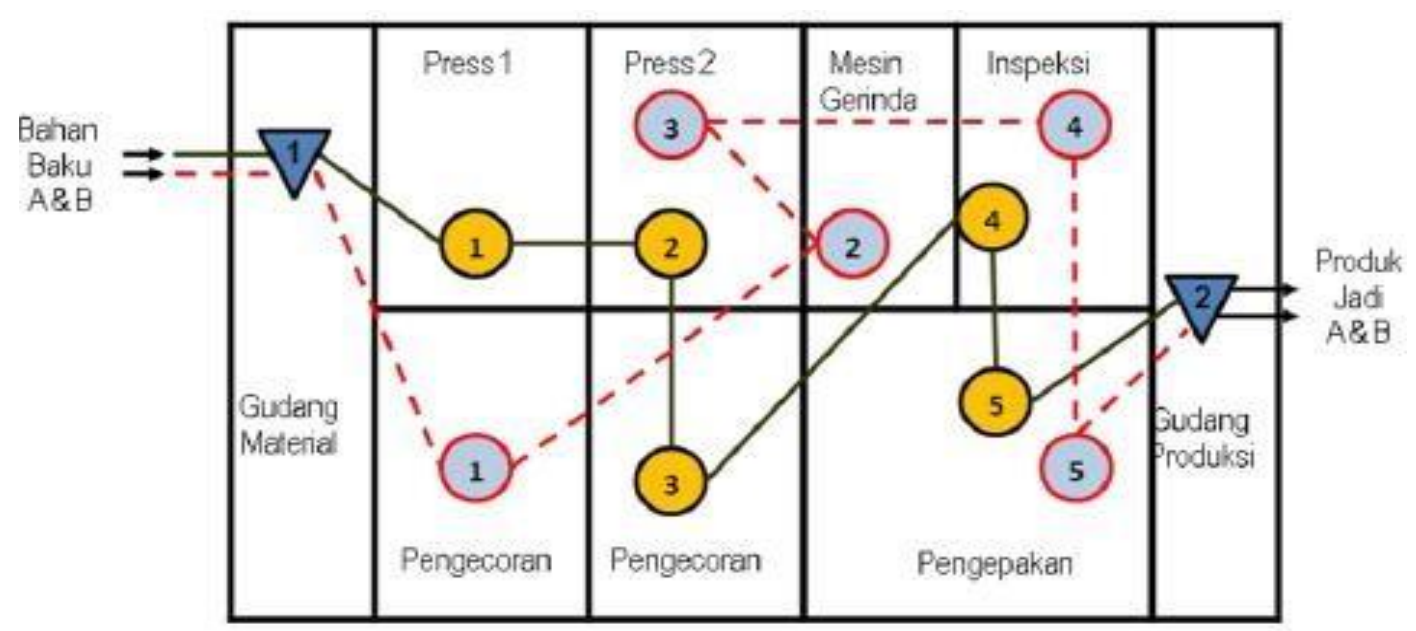

Fig 2:- Facility Layout Based on Production Flow

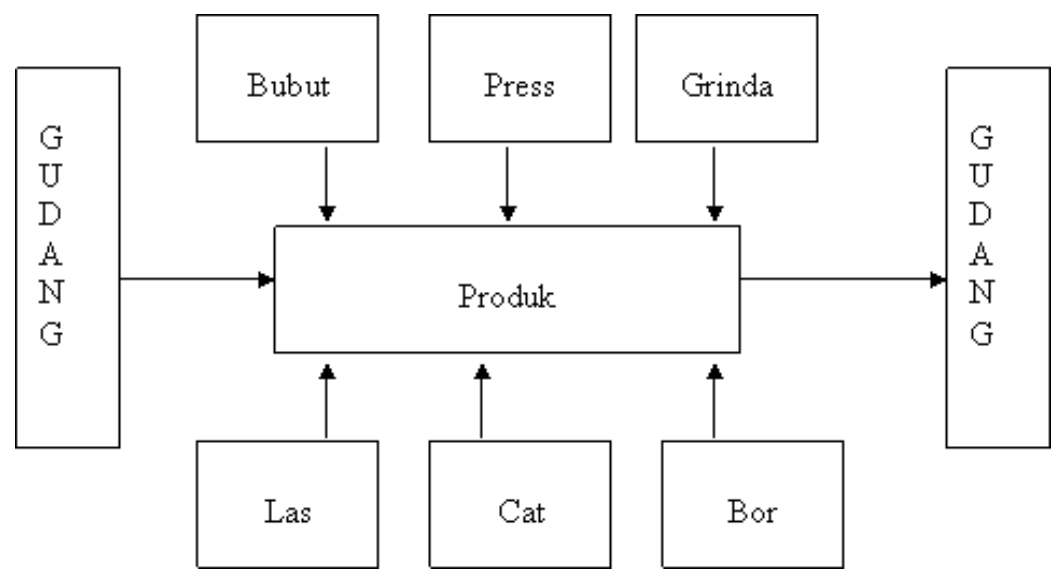

Fig 3:- Facility Layout Based on Fixed Material Location 


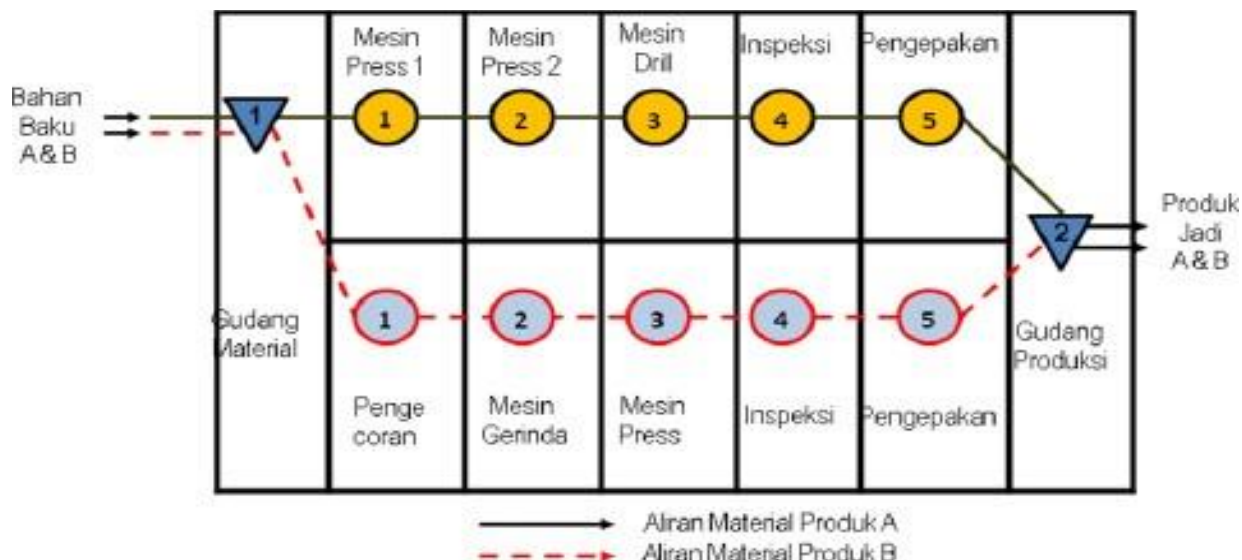

Fig 4:- Facility Layout Based on Product Groups

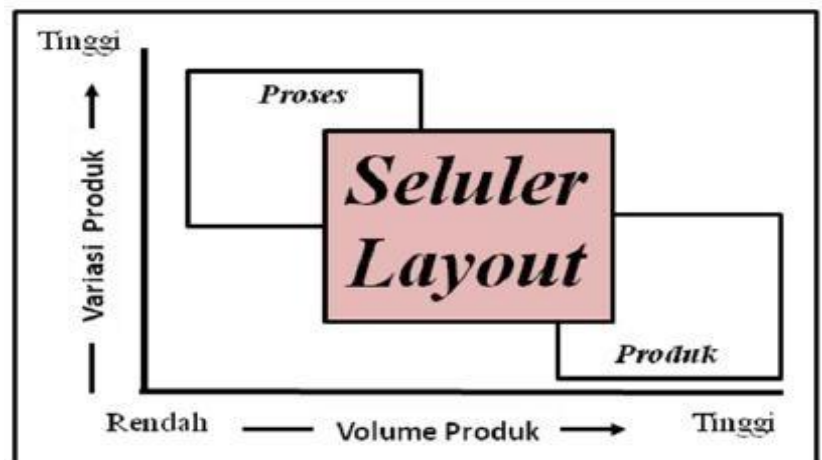

Fig 5:- Facility Layout Based on Function or Kind of Process

\section{Planning of Production Facility Layout}

Production facility is something that is built, held or invested to carry out production activities. According to Apple (1990, p. 2), "Facility Designers analyze, conceptualize, design and realize systems for the manufacture of goods or services. This design is generally described as a floor plan, namely an arrangement of physical facilities (equipment, tana, buildings, and other facilities) to optimize the relationship between implementing officers, the flow of goods, information flow and the procedures needed to achieve business objectives in a real, economical and secure." Generally the overall goal of designing a facility is to bring input (materials, supplies, etc.) through each facility in the shortest possible time, at a reasonable cost.

\section{Cycle Time of Production}

Is the time required to make one product unit of one station. If the production time and production targets have been determined, then the cycle time can be known from the results for the production time and production targets.

In designing the balance of the production line for a certain number of production, the cycle time must be equal to or greater than the biggest operating time which is the cause of the bottleneck of bottlenecks) and the cycle time must also be equal or smaller than the effective working hours per day divided by the number of production per day , which is mathematically stated as follows

$$
\text { ti } \max \leq C T \leq \frac{P}{Q}
$$

Explanation:

ti max : greatest operating time on the track

CT : cycle time production

$\mathrm{P} \quad$ : effective working hours per day

Q : amount of production per day

\section{Designing the layout using systematic layout planning} method.

Terdapat 5 elemen untama yang harus diperhatikan dalam SLP yaitu : Produk (Produk/P) ; Kuantitas (Quantity/Q); Proses (Routing/R); Sistem/Pendukung (Supporting System/S); dan waktu (Timer/T).

Systematic Layout Planning is a method used to produce a facility layout design with the most efficient flow of goods. This method puts forward the sequence of work processes and the degree of closeness between service units contained in the facility to be designed.

The stages of the layout design process can be described following the sequence of activities developed by Richard Muther, namely through an approach known as Systematic Layout Planning (SLP).

There are 5 main elements that must be considered in the SLP, namely: Products (Products / P); Quantity (Quantity / Q); Process (Routing / R); System / Support (Supporting System / S); and time (Timer / T). 


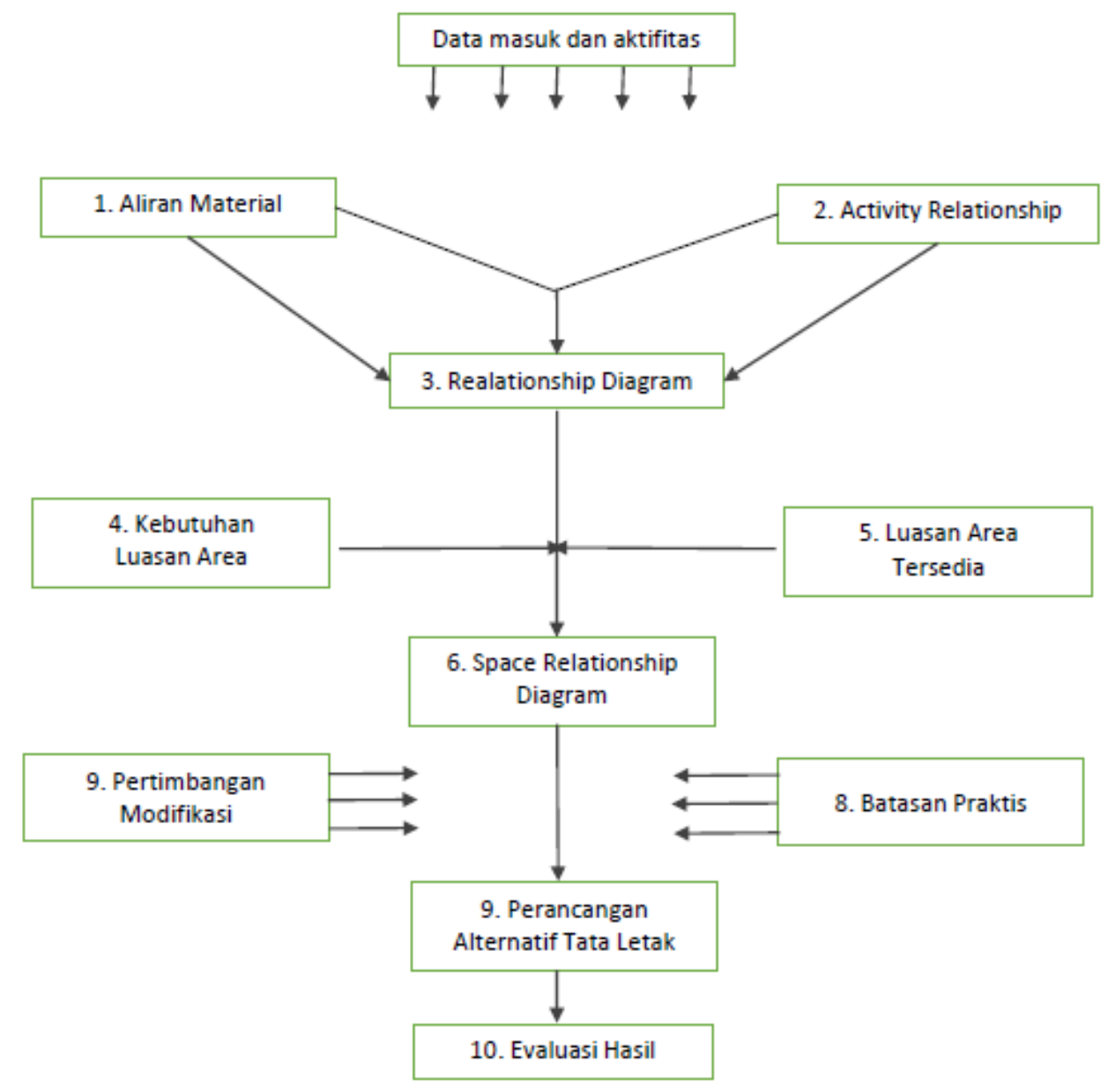

Fig 6:- Research literature with the Systematic Layout Planning (SLP) method

\section{METHODOLOGY}

The research began with an initial study at ABC Factory regarding company background and literature study based on the facility layout literature. After that, an observation of the environment and company production facilities is carried out. observations in the production system are based on theories regarding facility layout and material handling and identify existing production layouts. Until the end, problems were encountered at the PC Spun Pile production facility at ABC Factory.

In this study the analyst used the Systematic Layout Planning (SLP) method. This method analyzes the relationship between activities at each work station. As well as observing the placement of production machines and the number of production machines, this is related to the flow of materials during the production process. As well as the area available in existing conditions and possible space area which can be used as an alternative to the redesign of the layout of the PC Spun Pile production facility. After that, several alternative layout facilities will be made to be analyzed and determined the best option. 


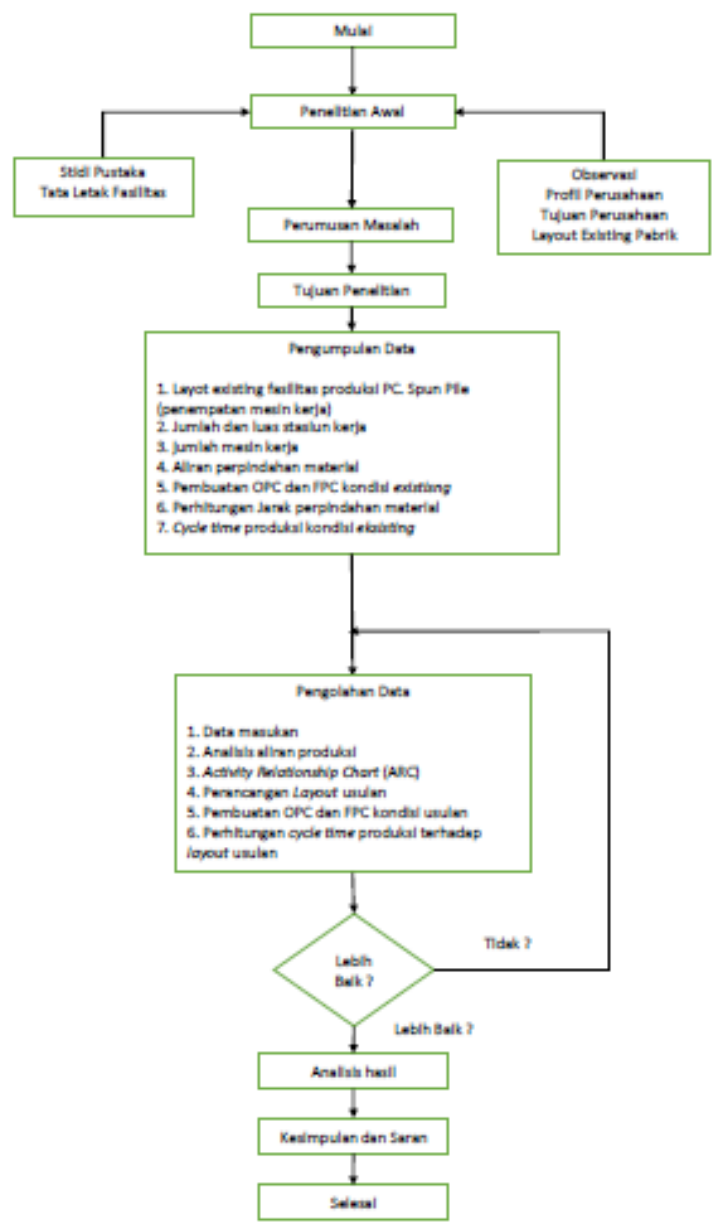

Fig 7:- Research Steps Diagrams

\section{RESULT}

\section{Analysis of Work Flow Process}

In the preparation of improving the layout of the PC Spun Pile production facility, there are several steps that must be implemented and described. To produce a good layout, the first step to improve the layout of the Spun Pile PC production facility is by processing data.

At the existing work station there are alternating production flows so that it interferes with the work process at other work stations. That was caused by the factor of material handling and safety methods applied to the PC Spun Pile production process. The handling method is carried out using Over Head Crane (OHC), which when operating will pass through other work stations and also takes into account the burden of goods being lifted weighing 2-7 tons.

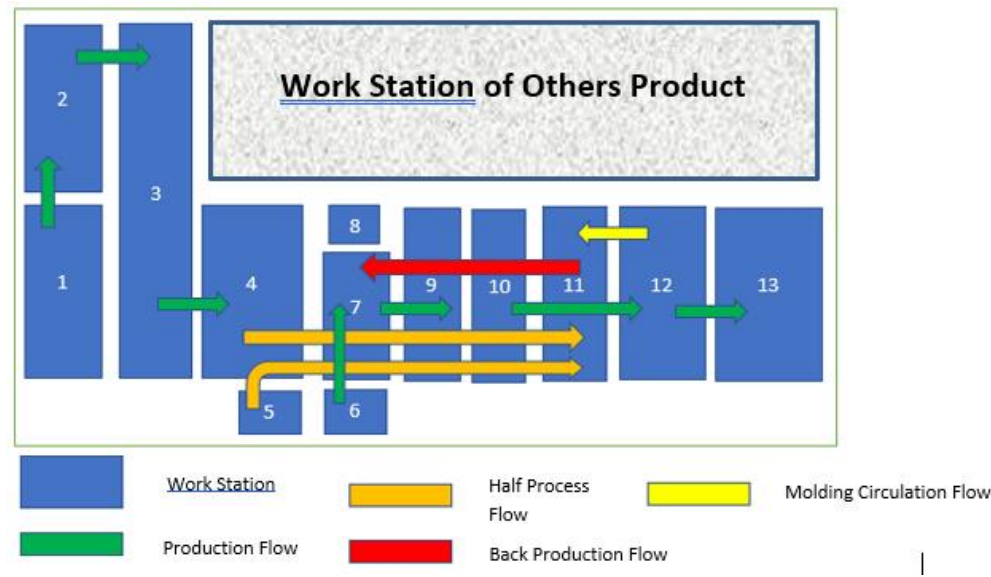

Fig 8:- Flow of production of Initial Condition Layout. 
Explanation :

1. Warehouse of Iron

2. Work Station of Cutting and Heading Process

3. Work Station of Forming Process

4. Work Station of Setting Process (Setting 2)

5. Work Station of Pencil Shoe Production

6. Work Station of Concrete Mixxing Process

7. Work Station of Concrete Placing Process

8. Work Station of Tension Process

9. Work Station of Spinning Process

10. Work Station of Drying using Steam Boiler

11. Work Station of Setting Process (Setting 1)

\section{Work Station of Demolding Process} 13. Stock Area

In the layout of the existing PC Spun Pile production facility above, it can be seen that the production flow is dominated by only one line, resulting in overworking of heavy equipment to lift equipment and affecting the smooth production process at the production facility.

After direct observation and work time measurements at each work station, get the average cycle time as follows:

\begin{tabular}{|c|c|c|}
\hline No & Steps of Production & $\begin{array}{c}\text { Time } \\
\text { (minute) }\end{array}$ \\
\hline 1 & Cutting Proces & 0.93 \\
\hline 2 & Heading Process & 2.10 \\
\hline 3 & Forming Process & 1.50 \\
\hline 4 & Setting Process & 1.80 \\
\hline 5 & Pencil Shoe Production Process & 2.80 \\
\hline 6 & Mixing Process & 4.25 \\
\hline 7 & Concrete Placing Process & 4.42 \\
\hline 8 & Tention Process & 1.52 \\
\hline 9 & Spinning Process & 7.50 \\
\hline 10 & Steam Curing & 9.60 \\
\hline 11 & Demolding Process & 1.30 \\
\hline & Total & $\mathbf{3 7 . 7 6}$ \\
\hline
\end{tabular}

Table 1:- Table of Cycle Time PC. Spun Pile Production

In the production process of PC Spun Pile piles there are several work processes that can be carried out in conjunction with other work processes, the work process is the Making of Pencil Shoes (no. 5) and Mixing Concrete Materials (no. 6). So the time needed to produce one PC Spun Pile is 30.67 minutes.

\section{Activity Relation Chart (ARC)}

From the observations on the work flow at the PC Spun Pile pile production facility and the information from the Deputy Production department, the ARC diagram is obtained as follows:
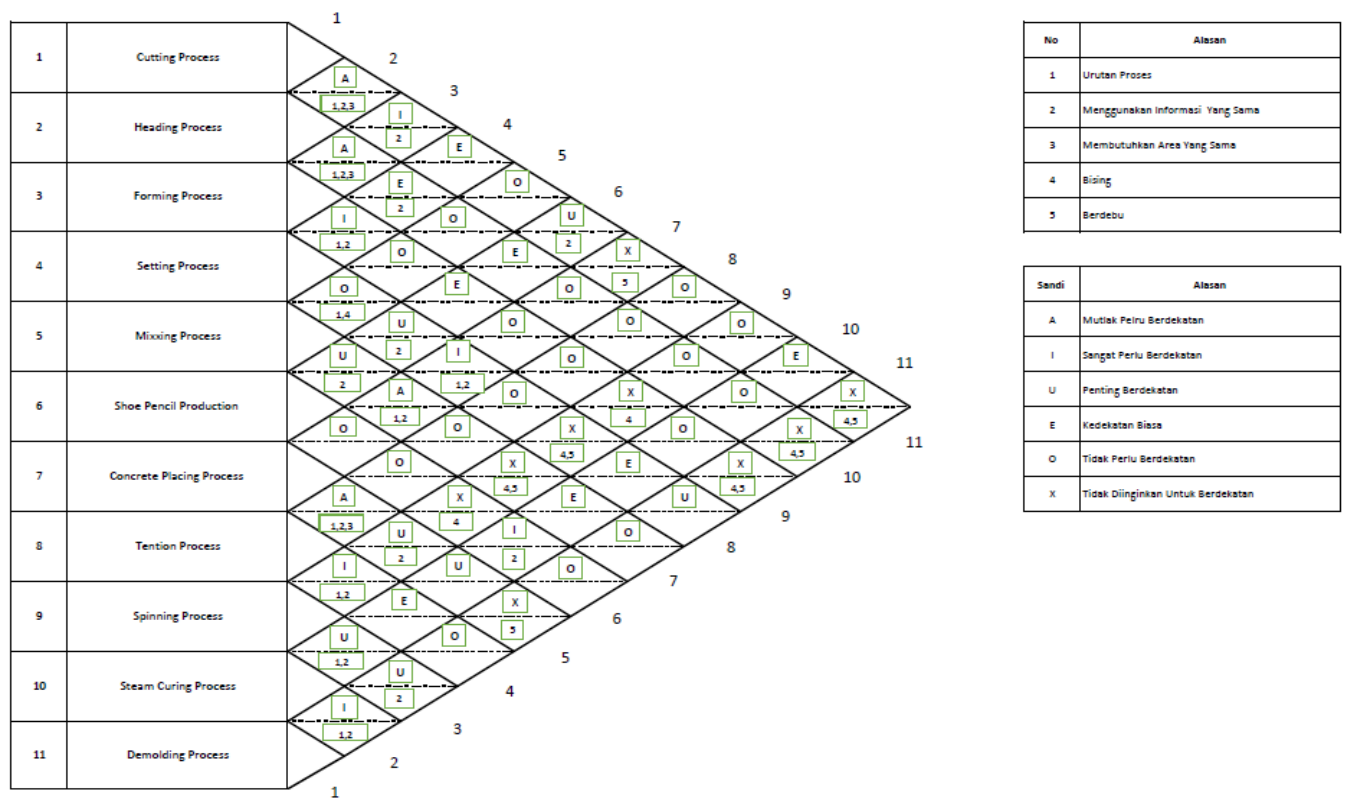

Table 2:- Activity Relationship Chart (ARC) PC. Spun Pile pile production process Purposed Condition. 


\section{Design of Production Facility Layout}

In making the proposed layout / layout the main objective is the smooth flow of work / flow from one work station to another work station. In re-designing the layout of the PC. Spun Pile pile production facility layout, the production facility layout was used at the ABC Factory plant in Tangerang. Where the plant is felt to be the most productive among the factories / other production plants. The layout of the Tangerang factory / plant production can be seen in the picture. 4.21 follows:

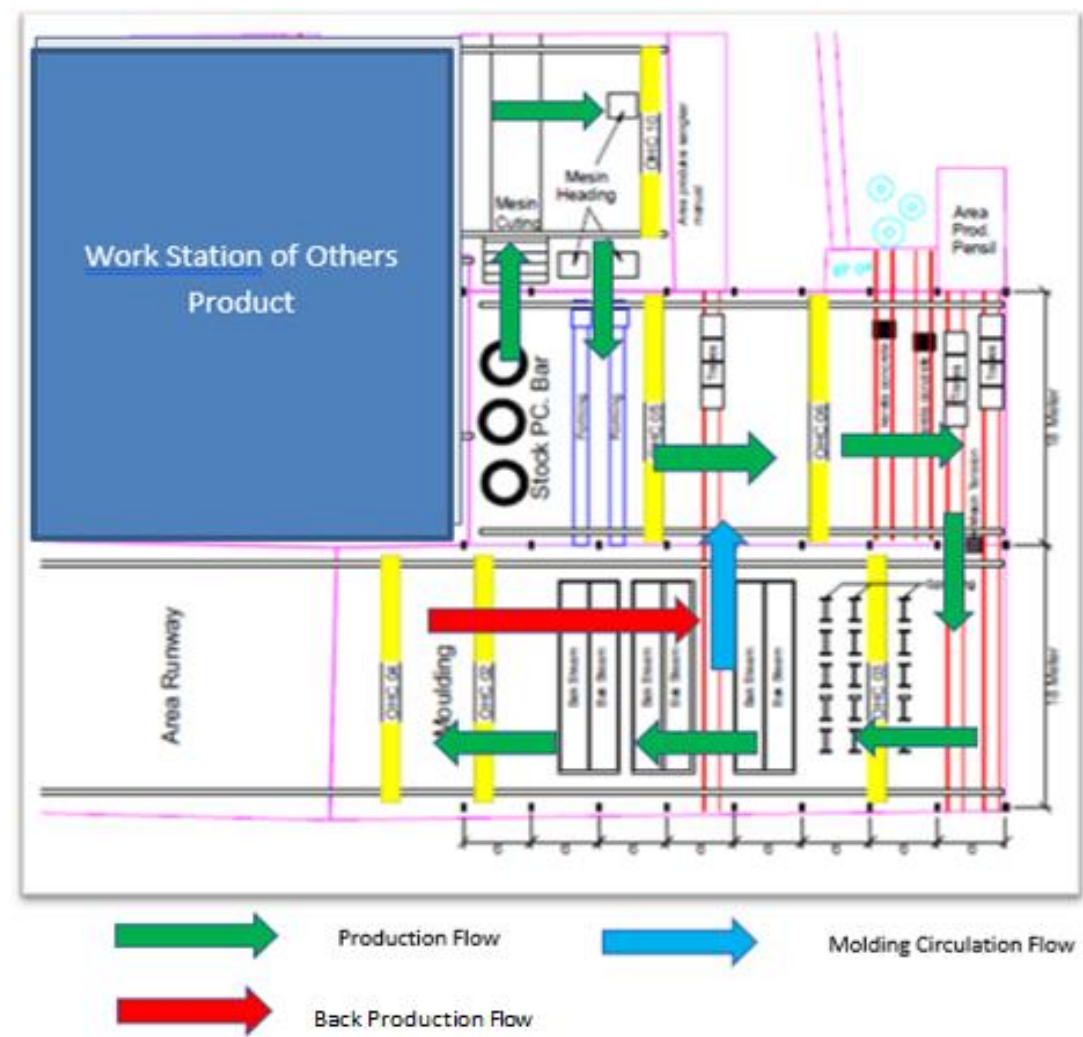

Fig 9:- Production Facility Layout of PC. Spun Pile in Tangerang Factory.

After observing the production flow and the arrangement of the existing work stations at ABC Factory factory / plant Tangerang, a redesign of the production layout at the factory / sadang plant was adopted by slightly adopting the main production flow and making improvements at several work stations. The following is the draft layout of the proposed PC Spun Pile production facility that has been made:

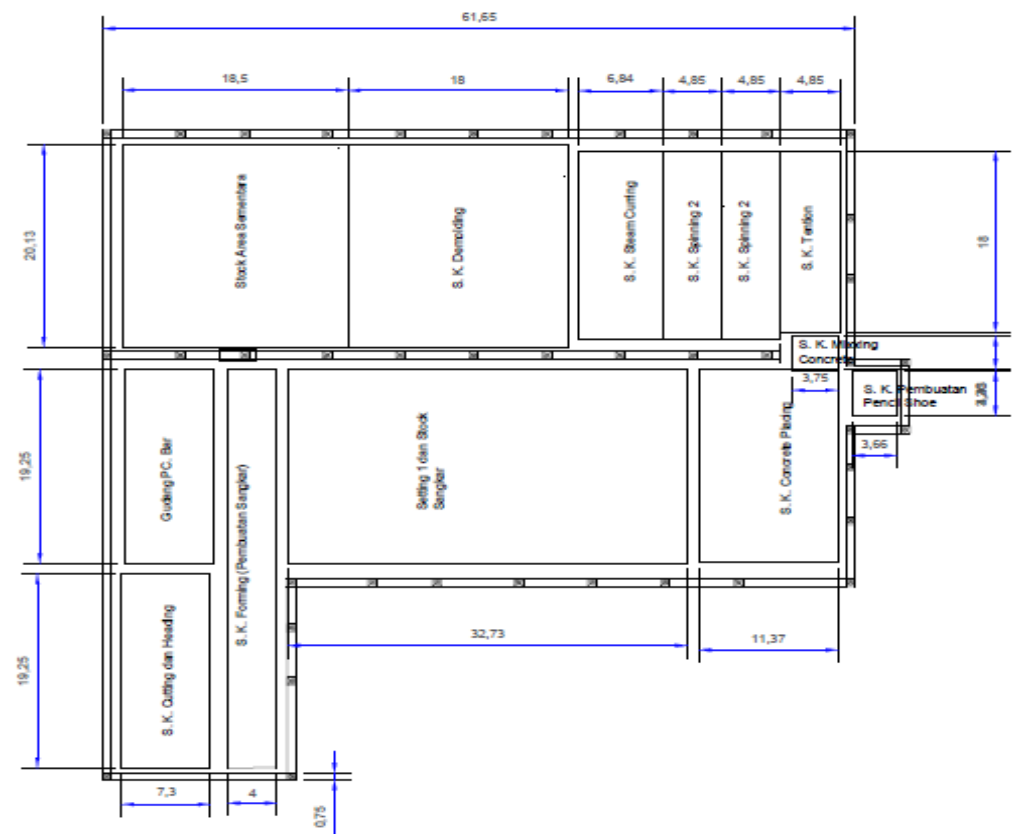

Fig 10:- Production Facility Layout of PC. Spun Pile in Sadang Factory (Propous Condition). 
The picture above is a layout design of PT. Jaya Beton Indonesia plant Sadang conditions of the proposed results of the adoption of the plant layout of ABC Factory Tangerang. In addition to adopting a form of production flow, improvements also occurred in work systems at several work stations.

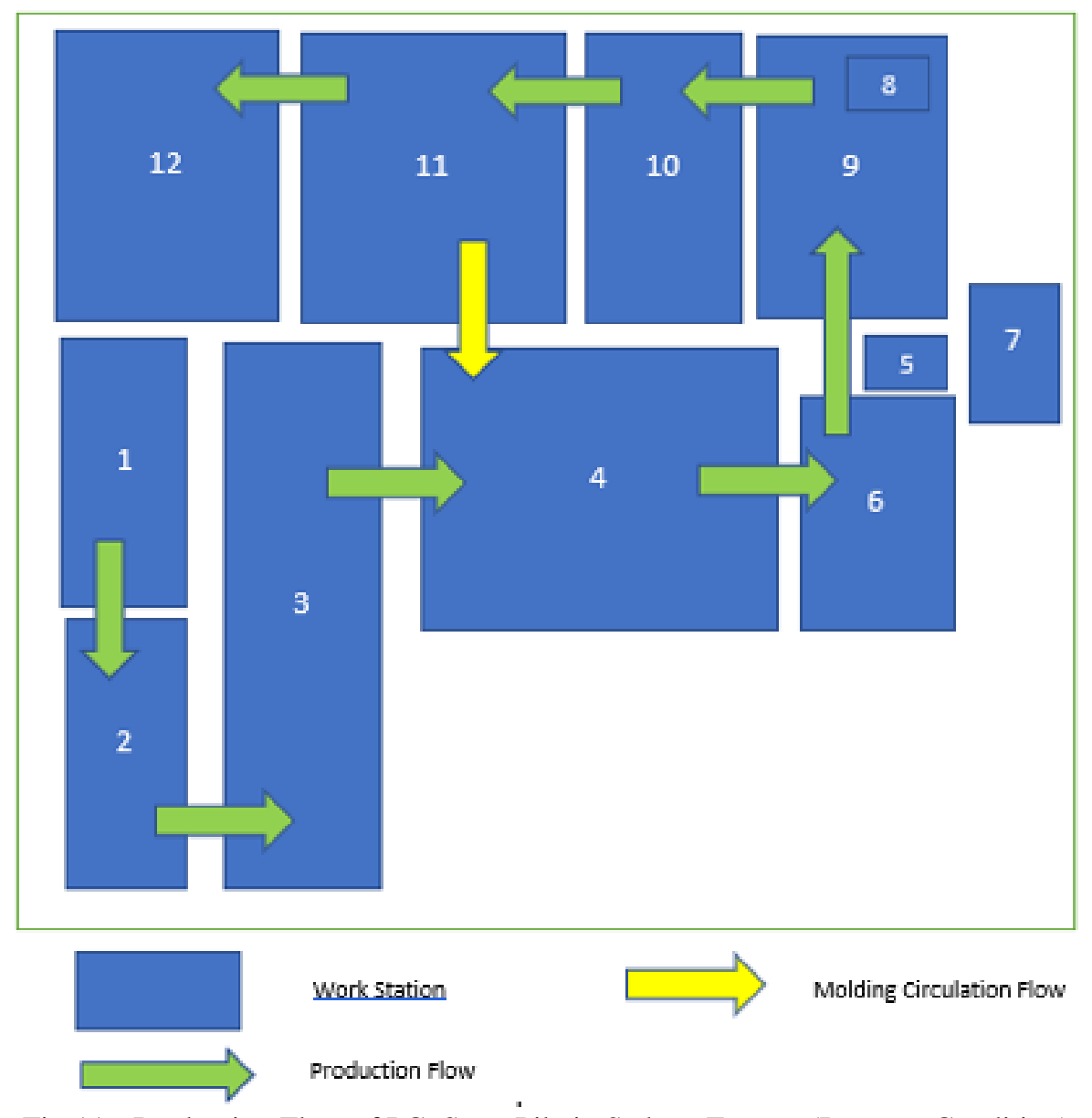

Fig 11:- Production Flow of PC. Spun Pile in Sadang Factory (Purpous Condition).

\section{Distance of Material Handling}

Material transfer data is needed to determine the efficiency of distance transfer / material handling between the initial condition layout and the proposed conditions. The following is the material transfer data from the analysis that has been done:

\begin{tabular}{|c|c|c|c|c|c|}
\hline No & From & To & $\begin{array}{c}\text { Distance } \\
\text { (meter) }\end{array}$ & Frequency & $\begin{array}{l}\text { Total Distance } \\
\text { (meter) }\end{array}$ \\
\hline 1 & Warehous Of Irone & W.S. Cutting \& Heading & 22 & 1 & 22 \\
\hline 2 & W.S. Cutting \& Heading & W.S. Forming & 6.65 & 1 & 6.65 \\
\hline 3 & W.S. Forming & W.S. Setting 1 & 6.2 & 1 & 6.2 \\
\hline 4 & W.S. Setting 1 & W.S. Setting 2 & 42.55 & 1 & 42.55 \\
\hline 5 & W.S. Pencil Shoe Production & $\begin{array}{c}\text { W.S. } \\
\text { Setting } 2\end{array}$ & 57.55 & 1 & 57.55 \\
\hline 6 & W.S. Setting 2 & W.S. Tension \& Concrete Placing & 36.94 & 1 & 36.94 \\
\hline 7 & W.S. Tension Process & W.S.Spinning & 13.71 & 1 & 13.71 \\
\hline 8 & W.S. Spinning & W.S.Drying & 7.68 & 1 & 7.68 \\
\hline 9 & W.S. Drying & W.S.Demolding & 26.89 & 1 & 26.89 \\
\hline 10 & W.S. Demolding & Stock Area & 18.75 & 1 & 18.75 \\
\hline \multicolumn{5}{|c|}{ Total } & 238.92 \\
\hline
\end{tabular}

Table 3:- Table distance of material handling initial condition. 
ISSN No:-2456-2165

\begin{tabular}{|c|c|c|c|c|c|}
\hline No & Dari & Ke & Jarak (m) & Frekuensi & $\begin{array}{c}\text { Total Jarak } \\
(\mathbf{m})\end{array}$ \\
\hline 1 & Warehous Of Irone & $\begin{array}{c}\text { W.S. Cutting \& } \\
\text { Heading }\end{array}$ & 20.3 & 1 & 20.3 \\
\hline 2 & $\begin{array}{c}\text { W.S. Cutting \& } \\
\text { Heading }\end{array}$ & W.S. Forming & 7.07 & 1 & 7.07 \\
\hline 3 & W.S. Forming & W.S. Setting & 19.93 & 1 & 19.93 \\
\hline & W.S. Setting & $\begin{array}{c}\text { W.S. Concrete } \\
\text { Placing }\end{array}$ & 26.03 & 1 & 26.03 \\
\hline 4 & $\begin{array}{c}\text { W.S. Pencil Shoe } \\
\text { Production }\end{array}$ & $\begin{array}{c}\text { W.S. Concrete } \\
\text { Placing }\end{array}$ & 23.43 & 1 & 23.43 \\
\hline 5 & W.S. Concrete Placing & W.S. Tension & 22.15 & 1 & 22.15 \\
\hline 7 & W.S. Tension & W.S.Spinning & 7.46 & 1 & 7.46 \\
\hline 8 & W.S.Spinning & W.S.Drying & 8.27 & 1 & 8.27 \\
\hline 9 & W.S.Drying & W.S.Demolding & 13.32 & 1 & 13.32 \\
\hline 10 & W.S.Demolding & Stock Area & 18.25 & 1 & 18.25 \\
\hline & \multicolumn{7}{|l}{ Total } & & 166.21 \\
\hline
\end{tabular}

Table 4:- Table distance of material handling puspose condition

From the above data there is a deviation in the distance of material handling between the layout of the initial conditions and the usual conditions. This deviation affects the duration of changes in the production process. Deviations that occur can be searched by the following formula:

\section{Deviation of Distance}

Material Handling = Initial Distance - Purpous Distance $=238,92$ meter $-166,21$ meter

$$
=72,71 \text { meter }
$$

The deviation causes a change in the production cycle time in the proposed layout. Cycle Time deviation can be found using the following formula:
Cycle Time Deviation $=$ Deviation of Material Handling (meter) Speed of Over Head Crane (meter/Minute)

$$
=\frac{72,71 \text { meter }}{20 \text { meter } / \text { minute }}
$$

\section{Result of Cycle Time Purpous Condition}

$=3.63$ minute

Based on the degree of closeness between work stations in the Operation Process Chart (OPC) and the arrangement of work stations in PC production facilities. Spun Pile proposed conditions, obtained cycle time at each work station as follows :

\begin{tabular}{|c|c|c|}
\hline No & Steps of Production & $\begin{array}{c}\text { Time } \\
\text { (minute) }\end{array}$ \\
\hline 1 & Cutting Process & 0.93 \\
\hline 2 & Heading Process & 2.10 \\
\hline 3 & Forming Process & 1.50 \\
\hline 4 & Setting Process & 2.81 \\
\hline 5 & Mixing Process & 2.80 \\
\hline 6 & Mixing Process & 4.25 \\
\hline 7 & Concrete Placing Process & 3.43 \\
\hline 8 & Tention Process & 1.52 \\
\hline 9 & Spinning Process & 7.50 \\
\hline 10 & Steam Curing & 6.24 \\
\hline 11 & Demolding Process & 1.01 \\
\hline \multicolumn{2}{|c|}{ Total } & $\mathbf{3 4 . 0 9 7}$ \\
\hline
\end{tabular}

Table 5:- Table of Cycle Time the Purpous Condition.

In the production process of PC Spun Pile piles there are several work processes that can be carried out in conjunction with other work processes, the work process is the Making of Pencil Shoes (no. 5) and Mixing Concrete Materials (no. 6). So the production cycle time needed to produce one PC Spun Pile pile is 27,035 minutes. Based on the cycle time produced from the layout of the proposed production capacity of PT. Jaya Beton Indonesia becomes 


$$
\begin{aligned}
& \text { Production Capacity }=\frac{\text { Total Working Hours }(\text { minute } / \text { bulan })}{\text { Cycle Time of production }\left(\frac{\text { minute }}{\text { pcs }}\right)} \\
& =\frac{31.500 \text { minute }}{27,035 \text { minute } / \mathrm{pcs}} \quad=1.165 \mathrm{pcs} / \mathrm{month}
\end{aligned}
$$

Comparison and Difference between Initial and Proposed Layout

After analyzing the initial layout and designing the proposed layout improvements, several comparisons were obtained. The following table 5.1 shows a comparison covering several things between the initial layout and the proposal.

\begin{tabular}{|c|c|c|c|}
\hline No & Description & Initial Layout & Usual Layout \\
\hline 1 & Production Flow & $\begin{array}{c}\text { There is alternating flow in some work } \\
\text { processes and mold circulation is hampered } \\
\text { by over head crane (OHC) activity density }\end{array}$ & $\begin{array}{c}\text { Circular production flow and } \\
\text { circulation of the story goes well }\end{array}$ \\
\hline 2 & Number of Work Stations & 13 Work Station & 12 Work Station \\
\hline 3 & Cycle Timeof Production & 30.67 Minute/Pcs & $27,035 \mathrm{Minute} / \mathrm{Pc}$ \\
\hline 4 & Production Capacity & $1.027 \mathrm{Pcs} / \mathrm{month}$ & 1.165 Pcs/Month \\
\hline
\end{tabular}

Table 6:- Table Comparation of Initial and Usual Condition

\section{CONCLUSION}

Based on research conducted on the redesign of the layout of the PC Spun Pile production facility at ABC Factory, the following conclusions are obtained:

$>$ With research using the Systematic Layout Planning (SLP) method to make improvements to the layout of the existing production facility layout, the layout design is better than the previous condition. Improvements occurred in the composition of the work stations which resulted in smoother production flow. In the layout design layout the production flow forms a "U" flow pattern and makes the PC Spun Pile molding circulating smoother. Improvements were also made to the efficiency of the work stations, where in the initial layout there were 13 work stations and after repairs the number of work stations changed to 12 work stations.

From the results of data processing and analysis, it is known that the production cycle time in the proposed layout is 27.035 minutes / stem or decreased by $11.85 \%$ from the previous production cycle time of $30.67 \mathrm{~min} /$ stem. And the production capacity of the production capacity produced by the proposed layout can reach 1,165 cigarettes / month or an increase of $13.44 \%$ from the previous production capacity of only 1,027 cigarettes / month.

\section{REFERENCES}

[1]. Ali Naqvi, S. A., Fahad, M., Atir, M., Zubair, M., \& Shehzad, M. M. (2016). Productivity improvement of a manufacturing facility using systematic layout planning. Cogent Engineering, 3(1). https://doi.org/10.1080/23311916.2016.1207296

[2]. Hartiwo, Y. M., \& Rimawan, E. (n.d.). Perancangan Simulasi Lacak Balak / Chain of Custody Material Pulp Dengan Skema Coc - Fsc Di Industri Kertas: Study Kasus Ikpp Tangerang Mill. XI(3), 300-314.

[3]. Hermawan, D. (n.d.). Peningkatan Produktifitas Kompor Gas Satu Tungku Melalui Perbaikan Tata Letak Fasilitas Di Pt Xyz. 152-163.
[4]. Hossain, R., Rasel, K., \& Talapatra, S. (2014). Increasing Productivity through Facility Layout Improvement using Systematic Layout Planning Pattern Theory. Global Journal of Researches in Engineering: J General Engineering, 14(7), 71-76.

[5]. Ojaghi, Y., Khademi, A., Yusof, N. M., Renani, N. G., \& Hassan, S. A. H. B. S. (2015). Production layout optimization for small and medium scale food industry. Procedia CIRP, 26(December), 247-251. https://doi.org/10.1016/j.procir.2014.07.050

[6]. Pangestika, J. W., Handayani, N., \& Kholil, M. (2016). Usulan Re-Layout Tata Letak Fasilitas Produksi Dengan Menggunakan Metode Slp Di Departemen Produksi Bagian Ot Cair Pada Pt Ikp. Jisi : Jurnal Integrasi Sistem Industri, 3(1), 29-38.

[7]. S. B. P. (2014). Productivity Improvement in Plant By Using Systematic Layout Planning (Slp) - a Case Study of Medium Scale Industry. International Journal of Research in Engineering and Technology, 03(04), 770-775. https://doi.org/10.15623/ijret.2014.0304136

[8]. Safitri, N. D., Ilmi, Z., \& Amin, M. (2018). Analisis Perancangan Tataletak Fasilitas Produksi menggunakan Metode Activity Relationship Chart (ARC). Jurnal Manajemen, 9(1), 38. https://doi.org/10.29264/jmmn.v9i1.2431

[9]. Shekhar Tak, C. (2012). Improvement in Layout Design using SLP of a small size manufacturing unit: A case study. IOSR Journal of Engineering, 02(10), 01-07. https://doi.org/10.9790/3021-021030107

[10]. Shewale, P. P., Shete, M. S., \& Sane, P. D. S. M. (2012). IMPROVEMENT IN PLANT LAYOUT USING SYSTEMATIC LAYOUT PLANNING ( SLP ) FOR INCREASED PRODUCTIVITY Address for Correspondence. I(Iii), 259-261.

[11]. Wiyaratn, W., \& Watanapa, A. (2010). Improvement plant layout using systematic layout planning (SLP) for increased productivity. World Academy of Science, Engineering and Technology, 72(12), 373377. 